\title{
Borges, Antólogo de sí Mismo
}

W el párrafo final del "Epílogo" a El bacedor, escrito a fines de rrollo de su obra en más de cuarenta años. Esta forma de recontar el retorno del hijo pródigo, explica: "Un hombre se propone la tarea de dibujar el mundo. A lo largo de los años puebla un espacio con imágenes de provincias, de reinos, de montañas, de bahías, de naves, de islas, de peces, de habitaciones, de instrumentos, de astros, de caballos y de personas. Poco antes de morir, descubre que ese paciente laberinto de líneas traza la imagen de su cara". ${ }^{1}$

Como culminación de la verdad borgiana, dos volúmenes recientes ordenan la suma de alusiones, intentadas por el autor y el acercamiento a una cifra que identifica las descripciones del mundo con quien las ha intentado.

El primero de estos libros, El bacedor, es un conjunto de ensayos, poemas, brevísimos relatos y confesiones autobiográficas, que Borges engloba bajo el nombre de "miscelánea"; suerte de diario compilado por el tiempo, durante los años que transcurren desde Otras inquisicio. nes (r952) hasta mediados de r960.2 En el citado "Epílogo" advierte:

1 El bacedor, Buenos Aires: Emecé Editores, 1960, p. 109.

El título corresponde a la primera histotia ensayo del volumen, interpretación de la ceguera de Homero, que concluye: "Con grave asombro comprendió. En esta noche de sus ojos mortales, a la que ahora descendía, lo guardaban también el amor y el riesgo. Ares y Afrodita, porque ya adivinaba (porque ya se acercaba) un rumor de gloria y de hexámetros, un rumor de hombres que defienden un templo que los dioses no salvarán y de bajeles negros que buscan por el mar una isla querida, el rumor de las Odiseas e Ilíadas que era su destino cantar y dejar resonando cáncavamente en la mernoria humana. Sabemos estas cosas, pero no las que sintió al descender a la última sombra" (p. 11).

Varias alusiones personales - los goces de la memoria, la ceguera física como iluminación espiritual, el sabor preciso de las experiencias, la perplejidad frente a lo casi eterno- se armonizan en esta historia simbólica.

2 Nacido en Buenos Aires en 1899, J. L. Borges viajó a Suiza con sus padres en 1914; cursó sus estudios secundarios en Ginebra, en 1918 pasó a España; en 1919 la revista Grecia (Madrid) publicó su primer poema; en 1921 regresó a 
"De cuantos libros he entregado a la imprenta, ninguno, creo, es tan personal como esta colccticia y desordenada silva de varia lección, precisamente porque abunda en reflejos y en interpolaciones. Pocas cosas me han ocurrido y muchas he leído. Mejor dicho: pocas cosas me han ocurrido más dignas de memoria que el pensamiento de Schopenhauer o la música verbal de Inglaterra".

Se anudan así confesiones parciales, siempre medidas, que se han ido escalonando desde 1920 ; la miscelánea de I960 esquiva lo sentimental directo, pero ya el escritor no se escuda entre los anaqueles de una biblioteca largamente leída y memorizada; justifica, en cambio, una vida $\sin$ grandes episodios públicos, aunque entrañablemente atenta al pais y su época. ${ }^{3}$

Fiel a confesiones anteriores, la ingenuidad crítica probaria que los ensayos, poemas y ficciones son el producto lúcido de la elaboración de lecturas constantes como si de tal manera se hurtasen los compromisos con el tiempo y el lugar en que el escritor ha vivido. La insistencia en lo que Borges llama sus "extravíos en la metafísica" serviría para apoyar la interpretación parcial de sus páginas. A tal coincidencia, debe sumarse que la difusión mayor de Borges -afirmada por traducciones y

Buenos Aires. La bibliografia borgiana incluye los siguientes títulos, fuera de las obras en colaboración y con seudónimo: Fervor de Buenos Aires (1923), Luna de enfrente (1925), El tamaño de mi esperanza (1926), El idioma de los argentinos (1928), Cuaderno San Martín (1929), Evaristo Carriego (1930), Discasión (1932), Historia universal de la infamia (1935), Historia de la eternidad (1936), El jardin de senderos que se bifurcan (1941), Ficciones (1944), El Aleph (1949), Otras inquisiciones (1952) y El bacedor (1961).

Enecé Editores ha emprendido el plan de publicación de las Obras comple. tas, de las cuales han aparecido nueve volúmenes (1953-1960). El autor no se ha conformado con la reedición textual de ninguno de sus libros; correcciones, supresiones $y$ adiciones confunden el orden cronológico de las primeras publicaciones. Sería importante una edición que agregase las variantes de los textos, al menos como fueron recogidos en libros, ya que entre las publicaciones (diarios, revistas) y en los volúmenes se observan cambios importantísimos. Han quedado fuera de los libros varios textos: poesías juveniles, ensayos y prólogos bocetos de relatos, notas bibliográficas, comentarios sobre estrenos cinematográficos, etc.

V. Bibliografía (en: Ana María Barrenechea, La expresión de la irrealidad en la obra de J. L. B., México: El Colegio de México, 1957, pp. 145-173. Alfredo A. Roggiano, en Diccionario de la literatura latinoamericana, Argentina. Sesunda parte (Washington: Unión Panamericana, 1961), pp. 257-258.

3 El mismo Borges ha difundido la visión libresca de su biografía: "Así, durante muchos años, ya creí haberme criado en un suburbio de Buenos Aires, un suburbio de calles aventuradas y de ocasos visibles. Lo cierto es que me crié en un jardín, detrás de un largo muro, y en una biblioteca de ilimitados libros ingleses" ("Agradecimiento a la demostración que le ofreció la Sociedad Argentina de Escritores", en Sur, Buenos Aires, núm. 129, julio de 1945, p. 120). En 1949 amplía esta confesión: "En el decurso de una vida consagrada menos a vivir que a leer, he verificado muchas veces que los propósitos literarios no son otra cosa que estímulos y que la obra final suele ignorarlos y hasta contradecirlos" (Otras inguisiciones [1937-1952]), Buenos Aires: Sur, 1952, p. 74. 
un premio internacional-corresponde a los relatos de Ficciones y El Aleph, volúmenes que comprenden una literatura cerrada a las mayorías. Adolfo Bioy Casares lo señaló a propósito de los primeros cuentos, aparecidos en la revista Sur: "Borges ha creado un nuevo género literario, que participa del ensayo y de la ficción; son ejercicios de incesante inteligencia y de imaginación feliz, carentes de languideces, de todo elemento bumano, patético o sentimental, y destinados a lectores intelectuales, estudiosos de filosofía, casi especialistas en literatura"."

Entre r940 y I950, la mayoría de los textos responden a los distingos señalados por Bioy Casares, con ausencia de los elementos que alcanzan el prestigio de los escritores populares. Tales rasgos continuan en algunas páginas posteriores, pero se diluyen en aquellas donde el autor se revela directamente, ya en resúmenes de etapas claves de la historia nacional, ya en sintesis de su propia existencia."

El otro libro decisivo para la comprensión de Borges es la Antologia personal, aparecida a fines de r96r. El "Prólogo" advierte: "Mis preferencias han dictado este libro. Quiero ser juzgado por él, justificado o reprobado por él, no por determinados ejercicios de excesivo y apócrifo color local que andan por las antologías y que no puedo recordar sin rubor". Sobre el distingo se reordenan las obras elegidas: "Al orden cronológico he preferido el de "simpatías y diferencias". He comprobado así, una vez más, mi pobreza fundamental; 'Las ruinas circulares', que datan de 1939, prefiguran 'El Golem' o 'Ajedrez', que son casi de hoy. Esta pobreza no me abate, ya qué me da una ilusión de continuidad". 6

En los párrafos prologales se condena la idea crociana de la expresión, exigencia (o desfiguración de una exigencia) a la cual "debemos la peor literatura de nuestro tiempo". Junto al rechazo, una explicación que alerta sobre el sentido de su obra vista en la totalidad: "Alguna vez yo también busqué la expresión; abora sé que mis dioses no me conceden más que la alusión o mención". Subrayado que llama la atención sobre la actual modalidad borgiana; punto de llegada que es también

A. Bioy Casares, "Prólogo" (en: J. L. Borges, S. Ocampo, A. Bioy Casares, Antología de la literatura fantástica, Buenos Aires: Editorial Sudamericana, 1940, p. 13).

Un extenso escolio al poema "La noche ciclica" (1940) concluye así: "En tiempos de auge la conjetura de que la existencia del hombre es una cantidad constante, invariable, puede entristecer o irritar; en tiempos que declinan (como éstos), es la promesa de que ningún oprobio, ninguna calamidad, ningún dictador, podrá empobrecernos" (Poemas [1922-1943]), Buenos Aires: Editorial Losada, 1943, p. 178 .

6 J. L. Borges, Antologia personal, Buenos Aires: Sur, 1961, p. 7. 
una forma de impulso insatisfactorio hacia la palabra única que nunca alcanzará a escribir. ${ }^{7}$

La Antología desdeña los poemarios iniciales, desde 1923 a $x 929$ -Fervor de Buenos Aires, Luna de enfrente y Cuadetno Sun Martiny los volúmenes de ensayos, con velados intentos narrativos, que se suceden desde Inquisiciones (1925) a Historia de la eternidad (1936). El material elegido corresponde a: Ficciones, que en I944 reunió El jardin de senderos que se bifurcan (r94.I) con Artificios; El Alepb (1949); Otras inquisiciones (1937-1952), del último año; El bacedor; y poemas posteriores a I940. En su totalidad, páginas de los últimos veinte años; importa la cronología, porque fueron escritas en paralelismo con los sucesos mundiales y argentinos de dos decenios de crisis.

La selección se inicia con un relato de base policial, "La muerte y la brújula", y se ciera con un poema abierto a la esperanza del Borges estudioso de todas las literaturas, "Composición escrita en un ejemplar de la gesta de Beowulf": "Será (me digo entonces) que de un modo / Secreto y suficiente el alma sabe / Que es inmortal y que su vasto y grave / Círculo abarca todo y puede todo. / Más allá de este afán $y$ de este verso / Me aguarda inagotable el universo". El contenido se ordena al.rededor del eje marcado por un ensayo extenso, "Nueva refutación del tiempo", que había circulado en edición privada de 1947 . Esta dilucidación metafísica explica al hombre Borges, erguido frente a un destino real y acosante (tigre, fuego y río); no importa la originalidad de las ideas expuestas, sino el ángulo desde el cual el escritor las selecciona y reitera, las comenta y hace suyas, hasta el párrafo final con esta inevitable concepción: "Negar la sucesión temporal, negar el yo, negar el universo astronómico, son desesperaciones aparentes y consuelos secretos. Nuestro destino (a diferencia del infierno de Swedenborg y del infierno de la mitología tibetana) no es espantoso por irreal; es espantoso porque es irreversible y de hierro. El tiempo es la substancia de que estoy hecho. El tiempo es un río que the arrebata, pero yo soy el río; es un tigre que me destroza, pero yo soy el tigre; es un

7 El poema "Mateo XXV, 30" (1953) sitúa la creación como pago de una deuda urgida por los dones que otorga la existencia. Este Juicio Final concluye: "Todo eso te fue dado, y también / El antiguo alimento de los héroes: / La falsía, la derrota, la humillación. / En vano te hemos prodigado el océano, / En vano el sol, que vieron los maravillosos ojos de Whitman; / Has gastado los años y te han gastado, / Y todavía no has escrito el poema" (Antolngía perso. mal, p. 39). 
fuego que me consume, pero yo soy el fuego. El mundo, desgraciadamente, es real; yo, desgraciadamente, soy Borges". 8

Una doble desgracia - realidad del mundo y realidad del hombre que la asume-aclara y relaciona los textos seleccionados; la presencia del escritor, que se pregunta a sí mismo y consulta a sus autores predilectos, elude las túrbaciones del ánimo, el impulso exclamativo y el apóstrofe, para apoyarse en la inteligencia, la más humana de las facultades. Si las circunstancias cotidianas reproducen el caos de los sueños, si nuestra infancia guarda tanto misterio como una ciudad hace tiempo enterrada, si los hombres aportan al mundo la ignominia y el herósmo, Borges penetra estas turbaciones y las ordena en estilo sin alardes ni temblores. Heroico en su labor creadora (menciones de la palabra inalcanzable), no se apoya en ningún credo religioso, en ningún sistema filosófico, en ninguna utopía política; consciente de la suma de tradiciones que en él confluyen y se reaniman, elige ser recatado y lúcido, de vigilante precisión clásica. ${ }^{9}$ La actitud del creador en el mundo y su época valen literariamente en tanto llegan a la originalidad intransferibile de un estilo; Borges se ha purificado de "literatura" hasta alcanzar su actual esencialismo verbal.

Desde los primeros ensayos, escritos poco después de I920, hasta nuestros días, ha teorizado con abundancia las posibilidades y los límites del escritor, convirtiéndose así en el mejor crítico de sus obras;

\section{Antología personal, p. 66.}

El "Prólogo" al ensayo coincide con la necesidad de afirmación en el desarrollo civilizador argentino: "Dedico estos ejercicios a mi ascendiente Juan Crisóstomo Lafinur (1797-1824), que ha dejado a las letras argentinas algún endecasílabo menorable y que trató de reformar la enseñanza de la filosofía, purificándola de sombras teológicas y exponiendo en la cátedra los principios de Locke $\mathrm{y}$ de Condillac. Murió en el destierro; le tocaron, como a todos los hombres, malos tiempos en qué vivir" (Antología personal, p. 49).

9 Los repetidos elogios de Borges a Quevedo y a escritores ingleses del siglo xvil han apoyado la idea de su barroquismo; la repitió hace poco J. B. Donne a propósito de la traducción norteamericana de Ficciones: "En estas breves fantasías - pocas de ellas superan la docena de páginas- encontramos la inventiva, improbabilidad y amor a la paradoja de un Chesterton embozado en el 'estilo barroco desarrollado por los escritores españoles e ingleses del siglo xvir; la inversímil amalgama del Padre Brown y Sir Thomas Browne" (en: La Nación, Buenos Aires, 21 de octubre de 1962).

La influencia barroca, evidente en los primeros libros, se va diluyendo a partir de 1940 para desaparecer luego; precisamente la novedad del estilo borgiano -en particular el narrativo- surge del despojo retórico y de la nitidez sintáctica $y$ verbal con que se precisan los mundos complejos de lo falaz. El escritor barroco del siglo xvir trató en cambio de cubrir con la abundancia de pompas verbales - herencia renacentista - una forma de nihilismo que retoma la idea de la vanidad de todo lo humano-raíz medieval de esa corriente expresiva. El nihilismo de Borges va por otros rumbos, abiertos por las circunstancias inmediatas; por lo demás, aparece superado en los últimos años. 
creador desdoblado en teórico - como Poe, como Valéry, como Eliot-, los aciertos e inclusive las arbitrariedades de los ensayos, resultan básicos para explicar su marcha hacia la posición que ilustra la Antologia personal. ${ }^{10}$

Hacia I925, adelantado en Buenos Aires del ultraísmo que testimonió en años madrileños y en cuya iniciación había colaborado, su concepto de la literatura creció sobre la condena de rezagos modernistas multiplicados por imitadores que prolongaban la extrañeza suntuosa de Prosas profanas. Atento a esa sola línea de Darío y sus continuadores abusivos, escribió entonces: "El rubenismo fue nuestra añoranza de Europa. Fue un suelto lazo de nostalgia tirado hacia sus torres, fue un largo adiós que rayó el aire del Atlántico, fue un sentirnos extraños y descontentadizos y finos. Tiempo en que Lomas de Zamora versificaba a Chipre y en que solemnizaban los mulatos acerca de Estambul, se descompuso para dicha de todos. Quede su eternidad en las antologías: queden muchas estrofas de Rubén y algunas de Lugones y otras de Marcelo del Mazo y ninguna de Rojas..."11

El desvío de extranjerizantes ingenuos, auténtico por el espejismo de una Europa múltiple y de un Oriente populoso en riquezas, le chocó a un hombre joven que había completado su adolescencia en el clima de la primera postguerra mundial, y que en sus días europeos había sufrido tenazmente la nostalgia de la patria, centrada en el Buenos Aires palermitano, entre signos que evocaban un pasado hecho de coraje individual y ternuras silenciosas.

Con el Borges que regresó a la Argentina en I92r, luego de seis años sumados entre Suiza y España, sucedió algo semejante a lo ocurrido con el iniciador del romanticismo rioplatense, Esteban Echeverría y, más cercano, con Baldomero Fernández Moreno, el mayor de los poetas que abrió en la Argentina las limitaciones retóticas del modernismo. Echeverría necesitó la experiencia de Europa y el choque posterior con el rosismo, para descubrir "el desierto" - la pampa-como la más pingüe

10 Una clara ordenación e interpretación de los textos críticos se encuentra en el inteligente estudio de Emir Rodríguez Monegal, "Borges: teoría y práctica" (en: Número, Montevideo, núm. 27, diciembre de 1955, pp. 124-157).

11. J. L. Borges, Alberto Hidalgo y Vicente Huidobro, Indice de la nueva poesía americana, Buenos Aires: El Inca, 1926, p. 15.

El mismo prólogo borgiano juzga con dureza a modernistas argentinos: a Lugones, lo llama "forastero grecizante, versador de vagos paisajes hechos a puro arbitrio de rimas y donde basta que sea azul el aire en un verso para que al subsiguiente le salga un abedul en la punta"; "De la Storni y de otras personas que han metrificado su tedio de vivir en esta ciudá (sic.) de calles derechas, sólo diré que el aburrimiento es quizá la única emoción impoética" (p. 16). 
de las materias literarias y hacerla protagonista de "La cautiva", el mejor de sus poemas. En Fernández Moreno, los primeros años de la infancia porteña se le hicieron nombre de una "Patria desconocida", que se diluía en la infancia y la adolescencia españolas; de regreso al país, el descubrimiento poético de lo cotidiano le dio el mejor venero al sencillismo de quien pudo ver con ojos nuevos lo que se le borra a aquellos que viven sumergidos en circunstancias habituales. ${ }^{12}$

En el balance de los años inmediatos al retorno, Borges insistió en lo regional; en lo inmediato y potteño: "Desde mil novecientos veintidós -la fecha es tanteadora: se trata de "una situación de conciencia que ha ido definiéndose poco a poco-; todo esto [el modernismo y sus huídas] ha cambiado. La verdad poetizable ya no está sólo allende el mar. No es difícil ni huraña: está en la queja de la canilla del patio y en el Lacroze que rezonga una esquina y en el claror de la cigarrería frente a la noche callejera". Ultraísta o simplista - no importa el rótulo de escuela-, el poeta trató de expresar esas verdades patrias sirviéndose de un conversado verso suelto y la suma de imágenes entrañables. Estas últimas-designación muy amplia que iguala los términos "traslación", "tropo" y "metáfora" - se convierten en el santo y seña de los nuevos, de los poetas que formarán el plantel revolucionario del periódico Martin Fierro entre 1924 y is927. A los "pleamares y mares de metáforas" se suman: la soltura idiomática, los avances del barbarismo, el neologismo y las voces arcaicas; el aprovechamiento consciente de los regionalismos porteños, tan válidos como los castizos de la Academia peninsular. ${ }^{13}$

El "sabor de patria" aparece con insistencia, por pasajes excesiva, en los primeros poemarios de Borges, ya enunciados por el énfasis cordial de los títulos. Actividad sólo aparentemente lúdica del poeta, ya que una línea de las primeras Inquisiciones confiesa el peso de la duradera inquietud metafísica en Fervor de Buenos Aires; se reconocía así el poder de afanes que van cercando los versos, desde los iniciales hasta los más recientes, los preferidos en la Antología personal. En éstos, al mismo tiempo que se depuran las notas locales (simples pretextos para el símbolo), se desdeñan el verso libre y el despilfarro de imágenes, para repetir el

12 V. sobre Esteban Echeverría, el sabio estudio de Battistessa (en: E. Echeverría, La cautiva. El matadero, Fijación de los textos, prólogo, notas y apéndice documental e inconográfico de Angel J. Battistessa, Buenos Aires: Peuser, 1958, pp. XIII-LXXVIII).

En cuanto a Fernández Moreno, la mejor explicación del retorno a la patria se encuentra en los capítulos correspondientes de sus "Memorias" (Vida, Buenos Aires: Editorial Kraft, 1957).

1.3 Indice de la nueva poesia americana, p. 17. 
rigor de estrofas como el cuarteto, de combinaciones estróficas como el soneto, de versos como el endecasílabo; apoyos del rigor reflexivo, apenas lírico, de los mitos que se renuevan.

Un poema escrito en 1955 , a poco del triunfo de la revolución antiperonista - "mil novecientos veintitantos"- - da el arqueo de la década del 20, evocando al Borges de entonces y al Ricardo Güiraldes de aquellos años plácidos. En un país que borró con prisa su anteayer, en una sociedad próspera y prometedora, los dos escritores intentaron interpretaciones míticas de personajes claves de la sociedad argentina. Güiraldes partió del paisano tropero- "resero" prefiere llamarlo- para elevar una trasposición ejemplar del gaucho a través de las dos figuras centrales de Don Segundo Sombra: el padrino sabedor de las destrezas rurales, dueño del silencio y la palabra justa, y el deslumbrado "guacho" que se haría hombre en "el más macho de los oficios", la resería. Borges, sin salir del perímetro de la casa paterna - Villa Alvear, en Palermo de Buenos Aires- acumuló las cifras del barric hacia I900, con noches peligrosas y guapos comentados por tangos agrestes, con casas bajas y calles abiertas al campo. No sólo cumplió esta evocación emotiva de un pasado que se desvanecía, sino que creó la mitología del poeta Evaristo Carriego, raíz sentimental del barrio y personaje inventado por sus propias estrofas. ${ }^{14}$

Mientras tanto, las fuerzas oscuras del país se iban alimentando con las formas agresivas del nacionalismo y del militarismo, reflejos de movimientos reaccionarios europeos; asalto de nuevas formas de barbarie que obligarian al escritor a fijarse y exponer su conducta; al mismo tiempo se esfucrza en la obra la relación con antepasados ilustres, o con quienes lucharon heroicamente contra bárbaros del siglo pasado. ${ }^{15}$

En momentos críticos de la vida argentina y de la conciencia borgiana, que pueden situarse hacia 1940, el escritor comenzó a aludir a las confusiones del presente nacional con las pesadillas y azares de sus mejores cuentos; luego de reunidos en Ficciones, el autor reanudó

I.t "Mil novecientos veintitantos" (El bacedor, p. 86). Los primeros versos parten de una concepción repetida en varios textos: "La rueda de los astros no es infinita / $\mathrm{Y}$ el tigre es una de las formas que vuelven, / Pero nosotros, lejos del azar y de la aventura, / Nos creíamos desterrados a un tiempo exhausto, / El tiempo en el que nada puede ocurrir".

Sobre la actitud de Guiiraldes, v. Juan Carlos Ghiano, Introducción a Ricudo Güiraldes, Buenos Aires: Ediciones Culturales Argentinas, Ministerio de Educación y Justicia, 1960.

1.5 En la Antologia personal se recogen numerosos textos que reafirman el entronque de Borges en la tradición cultural argentina. 
el repaso de sus planteos de crítico, cada vez más alejado de la euforia ultraísta del 20.

Una conferencia de 1951, en el Colegio Libre de Estudios Superiores de Buenos Aires, compendia con franqueza el itinerario hacia la literatura en que la expresión es reemplazada por la alusión; las referencias a las circunstancias pueden extenderse a los personajes de los relatos y las asunciones de existencia que cumplen. La confesión aclara: "Durante muchos añios, en libros ahora felizmente olvidados, traté de redactar el sabor, la esencia de los barrios extremos de Buenos Aires; naturalmente abundé en palabras locales, no prescindí de palabras como cuchilleros, milonga, tapia, y otras, y escribi así aquellos olvidables y ólvidados libros; luego, hará un año, escribí una historia que se llama "La muerte y la brújula", que es una suerte de pesadilla, una pesadilla en que figuran elementos de Buenos Aires deformados por el horror de la pesadilla; pienso allí en el Paseo Colón y lo llamo Rue de Tolon, pienso en las quintas de Adrogué y las llamo Triste-le-Roy; publicada esa historia, mis amigos me dijeron que al fin habían encontrado en lo que yo escribía el sabor de las afueras de Buenos Aires. Precisamente porque no me habia propuesto encontrar ese sabor, porque me había abandonado al sueño; pude lograr, al cabo de tantos años, lo que antes busqué en vano".16

Sobre el rechazo del costumbrismo y las palabras locales, surgen las visiones, claves personalísimas de la vida argentina durante tres lustros; la persona Borges - ya en directa presencia, ya aludida- se mezcla en ellas con personajes reales e imaginarios, completando un sentido de la ficción que se fue preparando lentamente, entre timideces y reparos. El primer boceto narrativo de Barges puede leerse en una página del periódico Martin Fierro, en 1927; entre los ensayos de El idioma de los argentinos (1928) se incluye una historia, "Hombres pelearon", a guisa de ejemplo; el primer cuento original completa una serie de recreaciones reunidas con al título de Historiat universal de la infamia (1935), publicadas previamente en el diario porteño Critica entre I933 y I.934. La serie de personajes ignominiosos se cierra con el hoy popularizado "Hombre de la esquina rosada". ${ }^{17}$. Relato distinto a los que luego es-

16 "El escritor y la tradición" (en la última edición de Discusión, Buenos Aires: Emecé Editores, 1957, p. 157).

i7 "Leyenda policial" (en: Martin Fierro, Buenos Aires, núm. 31, 26 de febrero de 1927) es el borrador de "Hombres pelearon"; incluido en El idioma de los argentinos. La serie que forma Historia universal de la infania se presenta como "el irresponsable juego de un tímido que no se animó a escribir. cuentos y que se distrajo en falsear y tergiversar (sin justificación estética, al- 
cribirá Borges, ya que el tema local y el lenguaje porteñizado-de una primera persona suburbana que se confieza con el escritor-pertenecen a los textos desechados por la Antología personal.

La visión del protagonista de ese cuento se amplía y ahonda en poemas y cuentos de ambiente nacional para desarrollar un ejemplario sudamericano que tiene su manifestación maestra en "Poema conjetural" de 1943. Historias de raiz semejante - "Biografía de Tadeo Isidoro Cruz", "El guerrero y la cautiva", Martin Fienro, etc., cumplen con personajes que no obran sobre el mundo, sino que descubren en un momento de crisis el misterio de cada uno, síntesis de muchos, acaso de todos. Borges lo ha señalado con advertencia que vale para ficciones y poemas de homenaje civil: "Cualquier destino, por largo y complicado que sea, consta en realidad de un solo momento: el momento en que el hombre sabe para siempre quién es". ${ }^{18}$ Iluminación que se vuelca asimismo en el prólogo y el epílogo de $E l$ bacedor, y en las declaraciones que abundan en este libro. ${ }^{10}$

guna vez) ajenas historias"; "Hombre de la esquina rosada" había aparecido en el diario Critica con el título "Hombre de las orillas" y firmado con el seudónimo " $F$. Bustos".

En el volumen de ensayos Historia de la eternidad se recoge "El acercamiento a Almotásim"; cuatro años más adelante se publica "Pierre Menard, autor del Quijote" (en Sur, Buenos Aires, núm. 56, mayo de 1939).

18 "Biografía de Tadeo Isidoro Cruz (1829-1874)" (El Aleph, Buenos Aires: Editorial Losada, 1949, p. 57). Es la recreación de la biografía del Sargento Cruz, desde su nacimiento hasta su encuentro con Martín Fierro (I, c. IX, del poema de José Hernández).

19 El prólogo es una dedicatoria a Leopoldo Lugones. El recuerdo del suicida de 1938, director de la Biblioteca del Consejo Nacional de Educación, se confunde con el presente de Borges, director de la Biblioteca Nacional: "De una manera casi física siento la gravitación de los libros; el ámbito sereno de un orden, el tiempo disecado y conservado mágicamente". De tal identificación surge el sentido del ofrecimiento: "Mi vanidad y mi nostalgia han armado una escena imposible. Así será (me digo), pero mañana yo también habré muerto y se confundirán nuestros tiempos y la cronología se perderá en un orbe de sim. bolos y de algún modo será justo afirmar que yo le he traído este libro y que usted lo ha aceptado" (p.8).

En "Poema de los dones" del mismo libro (pp. 53-54) la ceguera física y el ámbito de la Biblioteca Nacional permiten la identificación con Paul Groussac, antiguo Director de la misma casa y ciego en sus últimos años: "Groussac o Borges, miro este querido / Mundo que se deforma y que se apaga/ En una pálida ceniza vaga / Que se parece al sueño y al olvido".

Tales unificaciones se relacionan con la pasión de Borges por señalar las raices de su continuidad argentina; los elementos metafísicos velan la confesión. Hay otra coincidencia valiosa para comprender el pudor de lo personal; los dos únicos poemas de amor de Borges fueron escritos en inglés, en 1934: "Prose, poems for I. J." (Poemas (1922-1943), pp. 157-160). El final del poema II adelanta el mundo de alusiones de los relatos y de El bacedor: "I can give you my lon. eliness, my darkness, the hunger of my heart; I am trying to bribe you with uncertainty, with danger, with defeat". 
A dicha conciencia de lo humano se suman ciertas constantes literarias, anotadas en el "Epilogo" a Otras imquisiciones: "Una, a estimax: las ideas religiosas o filosóficas por su valor estético y aun por lo que encierran de singular y de maravilloso. Esto es, quizá, indicio de un escepticismo esencial. Otra, a presuponer ( $y$ a verificar) que el número de fábulas o de metáforas de que es capaz la imaginación de los hombres es limitado, pero que esas contadas invenciones pueden ser todo para todos, como el Apóstol" "ino

El prólogo a La invenctión de Moyel, la novela de Bioy Casares, repite la admiración de Borges por la inventiva de los narradores, no por la penetración psicológica; capacidad de fabulación gustada en sus antologías de la literatura fantástica y del cuento policial.a1 Dentro de esos géneros narrativos - lo fantástico y lo policial-, las ficciones borgianas son menos inusitadas que razonadas, menos libradas al azar de los hallazgos horrorosos que al encadenamiento demostrativo de los hechos. De ahí el sentido de catarsis que tienen sus cuentos dentro de los acosos del sueño y del mundo; de la realidad hecha pesadilla, o intuida en delirios febriles.

Una página de Historia de la eterridad adelanta la posibilidad de percepción de lo abstracto a partir de un experiencia de muerte que le había permitido superar los límites de la vigilia. El ensayo señala: "Por ejemplo: la Necesidad, la Razón, la Postergación, la Relación, la Consideración, el Tamaño, el Orden, la Lentitud, la Posición, la Declaración, el Desorden. De esas comodidades del pensamiento elevadas a formas ya no sé qué opinar; pienso que ningún hombre las podrá intuir sin el auxilio de la muerte, de la fiebre o de la locura. Me olvidaba de otro arquetipo que los comprende a todos y los exalta: la Eternidad, cuya despedazada copia es el Tiempo".

20 Otras inquisiciones, p. 223.

V. la excelente reseña de Enrique Pezzoni, "Aproximación al último libro de Borges" (en: Sur, Buenos Aires, núm. 217-218, noviembre-diciembre de 1952, pp. 101-123).

21 J. L. Borges, Silvina Ocampo y Adolfo Bioy Casares, Antología de la literatura fantástica, Buenos Aires: Editorial Sudamericana, 1940; J. L. Borges y A. Bioy Casares, Los mejores cuentos policiales, Buenos Aires: Emecé Editores, 1943 ( $1^{\text {a }}$ serie) y 1951 ( $2^{3}$ serie); J. L. Borges y A. Bioy Casares, Cuentos breves $y$ extraordinarios, Buenos Aires: Editorial Raigal, 1955.

La "nota preliminar" de la última antología reitera: "Lo esencial de lo narrativo está, nos atrevemos a pensar, en estas piezas; lo demás es episodio ilustrativo, análisis psicológico, feliz o inoportuno adorno verbal" (p. 9).

52 Historia de la eternidad, Buenos Aires: Emecé Editores, 1953, p. 20. En el mismo ensayo se recuerda el casi relato "Sentirse en muerte", incluido en El idioma de los a'gentinos; el párrafo fundamental alude a una experiencia que reaparece en los cuentos: "Me sentí muerto, me sentí percibir abstracto del mun- 
Los años de la dictadura aguzaron esa aptitud que había vislumbrado casi en muerte; la enfermedad le aportó los delirios de la fiebre y su lucidez. Tales elementos habían aparecido, marginalmente, en algu* nos poemas; eran en ellos una forma de intimidad, una vía de posible personalización, acorde con el principio de que la "poesía es el descubrimiento de mitos o el experimentatlos otra vez con intimidad, no el aprovechar su halago forastero y su lontananza".:23

Sobre dicho principio, ya en un poema de r925 se postulaba el ideal de un estilo, reclamado en "Jactancia de quietud": "Yo solicito de mi verso que no me contradiga, y es mucho. Q Que no sea persistencia de hermosura, pero sí de certeza espiritual".2. Pedido de certidumbre que aúna los afanes metafísicos expresados a través de pesadillas y caos, de laberintos y magias; para ser fiel a esos misterios debió cumplir el despojo de los alardes verbales, como si su estilo se acercara al nivel significativo y definitorio reservado para el ensayo riguroso y el tratado filosófico.

Ficciones fue la primera respuesta madura a tal necesidad de clarificar el caos; forma de literatura entre ensayo y relato, sin antecedentes en lengua española. El cuento fantástico-lo recordará Borges-- es el más antiguo de los géneros literarios, nacido con la cosmogonía y la mitología; incluido en esa vieja corriente tradicional, Borges le sumó las justificaciones de su visión del mundo, previniendo el tono de páginas autobiográficas de $E l$ bacedon. Tales escolios se adelantan a los reparos de quienes consideran a los relatos como simples juegos intelectuales, o acaso bizantinos artificios eruditos. La conciencia del misterio (presente en mil formas), el peso de inexplicables leyes divinas, lo confuso

do: indefinido temor imbuido de ciencia, que es la mejor claridad de la metafísica. No creí, no, haber remontado las presuntivas aguas del Tiempo; más bien me sospeché el poseedor del sentido reticente o ausente de la inconcebible palabra eternidad. Sólo después alcancé a definir esa imaginación" (p. 40). La conclusión adelanta el sentido de dubitaciones enriquecidas en los relatos: "Derivo de antemano esta conclusión: la vida es demasiado pobre para no ser también inmortal. Pero ni siquiera tenemos la seguridad de nuestra pobreza, puesto que el tiempo, fácilmente refutable en lo sensitivo, no lo es también en lo intelectual, de cuya esencia parece inseparable el concepto de sucesión" (p.41). V. el cuento "El inmortal" (El Aleph, pp. 10-11, 15, 16, 20, 21-22, 27). 74.

"23 El idioma de los angentinos, Buenos Aires: M. Gleizer editor, 1928, p.

En el mismo volumen se condena la preferencia absorbente por la metáfora, motivo fundamental de su primera poética: "La más lisonjeada equivocación de nuestra poesía es la de suponer que la invención de ocurrencias y de metáforas es tarea fundamental del poeta y que por ellas debe medirse su valimiento. Desde luego confieso mi culpabilidad en la difusión de este error" (p. 55).

24 Poemas (1922-1943), p. 90. 
y adverso de la realidad, dan la médula de relatos y poemas elegidos en la Antologia personal. Los temas, escasamente variados, y el rigor de la claridad verbal encubren los elementos que identifican los símbolos con la visión ensombrecida de circunstancias nacionales y de acosos de la enfermedad (la ceguera, la incerteza, el delirio del recién operado). Tales motivos dan el punto de partida a desarrollos complejos-en contenido, no en expresión- de cuentos "que tienen un valor de verdaderas investigaciones sobre las posibilidades epistomológicas" - según reconocimiento de Alfonso Reyes. ${ }^{25}$

El relato más ilustrativo es "Tlön Uqbar, Orbis Tertius", inesperadamente ausente de la Antología. Creación de un orbe que parte de los temas literarios de una conversación amistosa: la ejecución de una novela "en primera persona", donde unos pocos lectores, "muy pocos lectores", llegarían a "la adivinación de una realidad atroz o banal". Un espejo que acecha desde la penumbra de una vieja quinta y un artículo enciclopédico apócrifo deparan los primeros datos sobre Uqbar, cuyas leyes y principios se pormenorizan en páginas de severos deslindes. Entre los predicados de ese continente creado por los hombres son esenciales los metafísicos y literarios. La metafísica es considerada "una rama de la literatura fantástica"; de los libros, "los de ficción abarcan un solo argumento, con todas las permutaciones imaginables. Los de naturaleza filosófica invariablemente contienen la tesis y la antítesis, el riguroso pro y el contra de una doctrina. Un libro que no encierra su contralibro es considerado incompleto".

Caracteres que justifican el tono de la falsa postdata de 1947 que alude al sentido recóndito del relato a la vez que justifica el mundo del autor: "Hace diez años bastaba cualquier simetría con apariencia de orden-cl materialismo dialéctico, el anitsemitismo, el nazismo-para embelesar a los hombres. ¿Cómo no someterse a Tlön, a la minuciosa y basta evidencia de un planeta ordenado? Inútil responder que la realidad también está ordenada. Quizá lo esté, pero de acuerdo a leyes divinas -traduzco: a leyes inhumanas- que no acabamos nunca de percibir. Tlön será un laberinto, pero es un laberinto urdido por los hombres, un laberinto destinado a que lo descifren los hombres". 26

Un espejo turbador y una enciclopedia falaz sugieren la descripción de un continente inventado por los hombres y factible de ser desen110.

25. Alfonso Reyes, El deslinde, México: El Colegio de México, 1944, p. 26 Ficciones, Buenos Aires, Sur, 1944, p. 36. 
trañado por la inteligencia. Frente a las maquinaciones de la ignominia y lo sobrehumano de las leyes divinas, Borges yergue un mundo a la medida de sus fuerzas intelectuales; rehabilitación del intelecto que se rehace y completa en pasajes de "Las ruinas circulares" (terror del hombre soñado por otro), "La lotería en Babilonia" (ciudad gobernada por "un infinito juego de azares") y "La biblioteca de Babel" (universo o biblioteca "ilimitada y periódica"). Camo "Tlön, Uqbar, Orbis Tertius", "La lotería en Babilonia" está escrita en primera persona; en aquella historia, hombres reales - Bioy Casares, Mastronardi, Martínez Estrada, Reyes, etc.-, se mezclan con personajes de ficción; en la segunda, todo el desarrollo traspone una experiencia personal: la de la Argentina en 1940. El mismo nivel fantástico alcanza otras experiencias reales, que sostienen las tramas y repiten los estímulos del escritor, en particular autores releídos.

Borges ha apuntado un censo heterogéneo de escritores largamente gustados: Schopenhauer, De Quincey, Stevenson, Mauthner, Shaw, Chesterton, Leon Bloy; el recuento se puede completar con datos de las distintas Inquisiciones: Quevedo, Coleridge, Carriego, Witman, Valéry, Kafka, Keats, José Hernández. En los relatos, las citas de estos autores alternan con citas de obras falsas y con escritores inventados por el narrador; para acentuar más los entrecruzamientos entre ficción y realidad, dice de "El Sur" - "acaso mi mejor cuento", comenta Borges en I944-: "Bástame prevenir que es posible leerilo como directa narración de hechos novelescos y también de otro modo". El relato que así se presenta está recorrido, en todo su desarrollo, por líneas autobiográficas: referencias a los antepasados de Borges, declaración de algunas predilecciones, estado posterior a una delicada operación quirúrgica, etc.27

La complejidad se enriquece en $E l$ Alepb, de donde se han tomado la mayoría de los relatos incluidos en la Antologia; agonias y angustias humanas de siempre, vividas en la red de malos años que ha apresado al escritor, se relacionan con el contenido mejor de Fiaciontes. Partiendo de una atendible clasificación de Emir Rodríguez Monegal, ${ }^{\text {te }}$ pueden

27 Cuento incluido en la nueva edición de Ficciones (Buenos Aires: Emecé Editores, 1956). V. "Posdata de 1956" al "Prólogo" de Attificios, p. 116.

28 V. artículo citado, p. 149.

Rodríguez Monegal señala el sentido último de las Ficciones como "metáforas de la realidad": "En el centro de estas ficciones hay un mensaje - nihilistaque no es difícil formular: el mundo coherente que creemos vivir, gobernado por la razón y fijado por el esfuerzo creador en perdurables categorias morales e intelectuales no es real. Es una invención de hombres (artistas y teólogos, filosofos $y$ visionarios) que se superpone a la realidad absurda, caótica, del mismo modo que la caprichosa creación de Tlön (obra de sabios también) se superpone 
ordenarse ambos volúmenes alrededor de cinco temas ( $u$ obsesiones) fundamentales, que se dilucidan con mayor nitidez en relatos claves: el efecto monstruoso de la inmortalidad en los hombres ("Funes el memorioso", "El inmortal"); las visiones del universo y del destino como pesadilla, o encarcelamiento en laberintos sin salidas ("Ia biblioteca de Babel", "La casa de Asterión"); las variantes del azar como leyes de un mundo irreductible a las solicitaciones de la inteligencia ("La lotería en Babilonia", "La escritura de Dios"); el imposible deslinde entre el Bien y el Mal, ya que el traidor se identifica en última instancia con el traicionado, y cada hombre puede ser todos los hombres ("Tres versiones de Judas", "Los teólogos"); la parcialidad de la creación literaria y artística, del quehacer filosófico y del desvelo erudito ("Pierre Menard, autor del Quijote", "La busca de Averroes"). En el final de este último relato, Borges se sitúa dentro de su creación, como juego de reflejos que se prolongan infinitamente: "Sentí, en la última página, que mi narración era un símbolo del hombre que yo fui mientras la escribía, y que, para redactar esa narración, yo tuve que ser aquel hombre y que, para ser aquel hombre, yo tuvo que redactar esa narración, y así hasta lo infinito (En el instante en que yo dejo de creer en él, "Averroes" desaparece)".29

Borges habría sido asi, y sucesivamente: Almotásim, Pierre Menard, Herbert Quain, el guardián de la Biblioteca de Babel, Funes el memorioso, el inmortal Homero, Judas, Tadeo Isidoro Cruz, Averroes. Rostros distintos de un hombre apresado por la realidad y el tiempo, agonista de las ficciones que lo acercan a una historia única, la suya.

Como una forma de reducir los elementos obsesivos de los relatos, pasajes irónicos, o de humorismo de lo cursi y lo trivial, encuadran dos de las fábulas más intensas: "El Aleph." y "El Zahir", en los cuales el autor cree "notar algún influjo del cuento "The crystal egg" (I889) de Wells". En "El Aleph", los comentados pasajes del largo y premiado

a esta realidad legislada que todos soñamos. El mundo, el real no el aparencial, ha sido creado por dioses subalternos y abunda en incongruencias, en imperfecciones, en sinsentido" (p. 149).

Los sucesos políticos argentinos ahondaron la lucha entre el mundo de la razón creado por la esperanza de los hombres y el de la bárbara realidad de la dic. tadura. Este conflicto apremió la instalación de Borges en los valores de una tradición: "Para los europeos y los americanos, hay un orden - un solo ordenposible: el que antes llevó el nombre de Roma y que ahora es la cultura de Occidente. Ser nazi (jugar a la barbarie enérgica, jugar a ser un viking, un tártaro, un conquistador del siglo xvi, un gaucho, con piel roja) es, a la larga, una imposibilidad mental y moral" -Declaración escrita el 23 de agosto de 1944, día de la liberación de Paris (Otras inquisiciones, p. 157).

29 El Aleph, p. 104. 
poema "La Tierra", del argentinísimo Carlos Argentino Daneri, se presentan como resultado de "la aplicación, la resignación y el azar"; elementos contrarios a los que Borges controla en sus creaciones; de tal manera, los planteos literarios de su desdoblamiento de crítico y creador se afirman en las páginas de ficción.

Como complemento de esa dualidad pueden analizarse los cuentos policiales y los relatos humorísticos escritos en colaboración con Adolfo Bioy Casares, bajo el seudónimo único de "H. Bustos Domecq": Seis problemas para Don Isidro Parodi, de 1942; Dos fantasias memorables y Un modelo para la muerte, de I946, éstos bajo el rubro de una falsa editorial de nombre sugerente: "Oportet \& Haereses". En los dos volúmenes últimos las citas —auténticas, enmascaradas, inventadas- van mostrando esas zonas de alivio en que el narrador se vuelca hacia la sátira literaria; Dos fantasías memorables es el mejor ejemplo de ridiculización del nacionalismo y del casticismo (formas adscriptas a actitudes políticas).

Los poemas, los ensayos y las ficciones de Borges conducen sin desvíos hacia el contenido miscelánico de El bacedor y a los aciertos y limitaciones de la Antología personal. ${ }^{30}$ Puede argüirse - y es af́gumento de algunos críticos- que el escritor escapa así a las acechanzas de la vida nacional, y de los compromisos de la literatura. La verdad es otra; los poemas escritos entre 1945 y 1955 y los relatos de esos mismos años son las ilustraciones previas de las confesiones reunidas en $E l$ bacedor. Una prosa del último volumen, Martín Fierro, señala la base desde la cual deben interpretarse las creaciones escritas durante la dictadura peronista: "Dos tiranías hubo aquí. Durante la primera, unos hombres, desde el pescante de un carro que salía del mercado del Plata, pregonaron duraznos blancos y amarillos; un chico levantó una punta de la

30 La Antologia personal selecciona los siguientes textos: "La muerte y la brújula", "La trama", "El sur", "Página para recordar al coronel Suárez, vencedor de Junín", "El muerto", "Mateo XXV, 30", "Funes el memorioso", "Nueva refutación del tiempo", "Límites", "Las ruinas circulares", "Ajedrez", "El Golem", "Infierno I, 32", "El' otro tigre", "Una rosa amatilla", "Baltasar Gracián", "A' un viejo poeta", "Parábola del palacio", "La muralla y los libros", "El enigma de Edward Fitzgerald", "Ariosto y los árabes", "La busca de Averroes", "Un soldado de Urbina", "El hacedor", "Everything and Nothing", "De alguien a nadie", "Formas de una leyenda", "El Zahir", "El Aleph", "La noche cíclica", "Alusión a una sombra de mil ochocientos noventa y tantos", "El tango", "Bio." grafía de Tadeo Isidoro Cruz", "El fin", "Historia del guerrero y de la cautiva", "El cautivo", "Paraíso XXXI, 108", "Lucas XXIII", "El testigo", "El pudor de la historia", "El milagro secreto", "Poema conjetural", "Poema de los dones", "La luna", "Arte poética", "Borges y yo": y "Composición escrita en un ejemplar de la gesta de Beowulf". 
lona que la cubría y vio cabezas unitarias con la barba sangrienta [recuerdo de Lucio V. Mansilla, el sobrino de Rosas, contado en Mis memorias]. La segunda fue para muchos cárcel y muerte; para todos un malestar, un sabor de oprobio en los actos de cada dia, una humilla. ción incesante. Estas cosas, ahora, son como si no hubieran sido". ${ }^{31}$ Las diferencias entre ambas barbaries destacan la sensación de pesadilla y malestar físico de la última; sorpresas de lo imprevisible, de lo difusamente morboso, de lo convencionalmente teatral, apoyan las opiniones borgianas de esos años, en juego de opuestos, y abiertas hacia símbolos infinitos. A la forma de oprobio indefinible se suma el sentido de representación - teatro dentro del teatro- que comenta, en otra prosa, las simulaciones de un falso enlutado que en los días de julio de 1952 armaba en El Chaco el velatorio de "la mujer Eva Duarte", reemplazada por una muñeca rubia: "Cifra perfecta de una época irreal", "reflejo de un sueño", "drama en el drama, que se ve en Hamlet". ${ }^{32}$

La crasa mitología inventada "para el crédulo amor de los arrabales" es trasposición caricaturesca de una monstruosidad nacional que interpreta a la dictadura en el mito, nacimiento y fin de una literatura: la fantástica. El ya comentado poema "Mil novecientos veintitantos" evoca la Argentina del pasado inmediato desde las persepectivas impuestas por el peronismo, para peculiarizar: "Yo tramaba una humilde mitología de tapias y cuchillos / Y Ricardo pensaba, en sus reseros"; para concluir: "No sabíamos que el porvenir encerraba el rayo, / No presentimos el oprobio, el incendio y la tremenda noche de la Alianza; / Nada nos dijo que la historia argentina echaría a andar por las calles, / La historia, la indignación, el amor, / Las muchedumbres como el mar, el nombre de Córdoba, / El sabor de lo real y de lo increíble, el horror y la gloria". ${ }^{33}$

Con dolor extraño y con angustia de ahogo, con asombro feliz ante lo heroico, se fueton manifestando las sorpresas; humillantes primero, con la alegría de la recuperación luego. Los poemas que dan los ejemplos perdurables de esa actitud cívica corresponden, desde 1943, a una línea casi siempre olvidada por los críticos de Borges: "Poema conjetural", "Página para recordar al coronel Súárez, vencedor en Junín", "Alusión a la muerte del coronel Francisco Borges (1835-74)", "Mil "novecientos veintitantos" y "Oda compuesta en 1960". Los versos fi-

\footnotetext{
B1 El bacedor, p. 35.

32 El bacedor, p. 21

33. El bacedor, p. 86 .
} 
nales de la última composición señalan la dualidad de amor y misterio que provoca la patria: "Eres más que tu largo territorio / Y que los días de tu largo tiempo, / Eres más que la suma inconcebible / De tus generaciones. No sabemos / Cómo eres para Dios en el viviente / Seno de los eternos arquetipos, / Pero por ese rostro vislumbrado / Vivimos y morimos y anhelamos, / Oh inseparable y misteriosa patria". ${ }^{34}$

De esta manera asienta una continuidad que alimentó las mejores creaciones de Borges, alerta así su conciencia de la compleja y sorpresiva América del Sur, dentro de la cual la Argentina volvía a erizar fallas y turbaciones. Hasta 1930 , nuestro país se gloriaba como nación aparte entre las confusiones de los otros países, manifestación de ese clima, entre tragedia y caricatura, de las Tierras Calientes diseñadas por Valle Inclán en los capítulos de Titano Banderas.

Desde la revolución de septiembre del 30 , se insolentaron los avan* ces del militarismo y del nacionalismo agresivo, remedos de movimientos totalitarios europeos; los escritores argentinos retornaron entonces a la preocupación por los diagnósticos aplicados a la historia contemporánea, ya sobre la añoranza de formas anteriores de la vida nacional, ya buceando en una continuidad de errores que confirman una biblica maldición de origen. El afán auscultador se adelantó, todavía contenido y esperanzado, en Historia de una pasión argentina, y se ensombreció con pasión de cauterio en Radiografía de la pampa y La cabeza de Goliati; incitados por Eduardo Mallea y por Ezequiel Martínez Estrada, novelistas y ensayistas completaron la misión de testimonio y denuncia. ${ }^{35}$

Inclusive las conciencias más alertas sintieron una impresión de malestar inexplicable, casi metafísico; lo prueba Martínez Estrada con sus relatos, presididos por Kafka y Strindberg, que tratan de describir el caos. La verdad de la crisis arrasó las visiones plácidas de una Argentina proyectada por el optimismo con que la generación de los proscriptos de la primera tiranía llegó al gobierno; el polémico ensayo del mismo Martínez Estrada, Sarmiento, impuso la necesidad del análisis de una figura señera de aquel período fundador ${ }^{36}$

\$4 El bacedor, p. 88.

33 Historia de una pasión argentina se publicó en 1937; Radiografia de la pampa, en 1933; La cabeza de Goliat, en 1940.

V. Luis Emilio Soto, Crítica y estimación. Buenos Aires: Sur, 1938; E. Ro. dríguez Monegal, El juicio de los parricidas, Buenos Aires: Ediciones Deucalión, 1956.

36 Ezequiel Martínez Estrada, Sarmiento, Buenos Aires: Argos, 1946. Los temas de este volumen se refuerzan en el genial ensayo Muerte y transfiguración del Martín Fierro, México: Fondo de Cultura Económica, 1948. 2 vols. Con posterioridad a 1955, Martínez Estrada reunió en libros sus relatos, claves de la 
El Borges testigo de la barbarie nueva se sintió apresado por un laberinto inviolable, donde se encerraban o eran encerradas sus criaturas, para que el relator interpretase tales límites con posibles versiones fantásticas. Esa pesadilla era el país; esas angustias, el resultado de la ignominia difundida y explotada; los nuevos destinos heroicos, una reiteración del sacrificio del Doctor Francisco Narciso de Laprida, asesinado el 22 de septiembre de 1829 por los montoneros del fraile Aldao. El estudioso de las Leyes y los Cánones, el Doctor cuya voz declaró la Independencia Argentina, había caído en la muerte marginal de las lanzas bárbaras; como el protagonista del poema de 1943, Borges asumia su destino sudamericano, cualquiera fuera la forma de reacción frente a la tiranía: "Yo que anhelé ser otro, ser un hombre / de sentencias, de libros, de dictámenes". Para afianzar esa asunción, "Página para recordar al coronel Suárez, vencedor en Junín", de r945, se cierra con afirmativa continuidad: "Junín son dos civiles que en una esquina maldicen a un tirano, / o un hombre oscuro que se muere en la cárcel".

Como reafirmación escribe la prosa "El puñal", publicada en Montevideo en 1954; el penúltimo párrafo compendia el sentido recóndito del homenaje: "En un cajón del escritorio, entre borradores y cartas, interminablemente sueña el puñal su sencillo sueño de tigre, y la mano se anima cuando lo rige porque el metal se anima, el metal que presiente en cada contacto al homicida para quien lo crearon los hombres". "Dureza", "fe", "impasible o inocente soberbia" son cualidades de esa estructura metálica que está invitando al tiranicidio; los elementos que habían sido ilustración de confusos corajes suburbanos, librados a la censura policial, se empinan como responsabilidad patria.

El contenido confesional de El hacedor abre las veladuras simbólicas de la obra anterior; ya no es sólo el destino nacional; es también la ceguera, la previsión de la muerte, el balance de la obra cumplida, la posibilidad de los textos que deparará el futuro, el homenaje a antecesores literarios y familiares. Las confesiones se ordenan desde la intención de los títulos: "Homero", "Poema de los dones", "Las uñas", "El testigo", "El reloj de arena", "El espejo", "La luna", "Los Borges", "Borges y yo"; el escritor aparece y reaparece transformado en figura literaria, manifestación del mito, según lo declara la prosa citada al final de la enumeración: "Seria exagerado afirmar que nuestra relación es

pesadilla peronista: Tres cuentos sin amor, Buenos Aires: Editorial Góyanarte, 1956; Marta Riquelme, Buenos Aires: Editorial Nova, 1956; Sábado de gloria, Buenos Aires: Editorial Nova, 1956. 
hostil; yo vivo, yo me dejo vivir, para que Borges pueda tramar su literatura y esa literatura me justifica. Nada me cuesta confesar que ha logrado ciertas páginas válidas, pero esas páginas no me pueden salvar, quizá porque lo bueno ya no es de nadie, ni siquiera del otro, sino del lenguaje o la tradición".37

Se amplía así la excusa que abre la colección de Poemas: "Si las páginas de este libro permiten algún verso feliz, perdóneme el lector la descortesía de haberlo usurpado yo, previamente. Nuestras nadas poco difieren; es trivial y fortuita la circunstancia de que seas tú el lector de estos ejercicios, y yo su redactor".3s Los goces personales-relojes de arena, mapas, tipografía del siglo xvil, sabor del café, prosa de Stevenson-; lo que le fue dado y lo que se ganó; los dones de su existencia le exigen respuesta y pago. Asi lo anota el poema "Mateo XXV, 30", preanuncio del Juicio que concibe la inteligencia borgiana, atribuido a una Divinidad indefinida: "He gastado los años y te han gastado, / Y todavía no has escrito el poema". El texto evangélico señalado en el título corresponde a la parábola de los talentos y ordena: "Ahora bien, a ese siervo inútil arrojadle a las tinieblas de afuera; allí será el llorar y el crujir de dientes".

Desde el balance - cómputo de vida y de literatura-que es $\mathrm{El}$ bacedor se comprende la Antología persond, seleccionada como coincidentes intentos de aludir a una preocupación borgiana: la permanencia del hombre llevado por la corriente del tiempo y circundado por el laberinto que encubre su vida. En reiteración de certezas crecidas desde el desorden extraño de la realidad, se explica y se justifica la selección, a la vez que su creador. Lo explica por el heroísmo de quien se sos. tiene entre quebrantos, recurriendo sólo a las posibilidades de la inteligencia; lo justifica en cuanto Borges no se traiciona a sí mismo ni contradice las posibilidades de su genio. Al desdeñar las utilerías regionalistas, al esconder su fondo de ternura, al reducir los aguijones de la ironía, al esquivar las formas sentimentaloides del amor y el sensualismo sexual, al reconocer como compromiso primera el del hombre consigo mismo y con los otros hombres - sin credos, ni rotulaciones políticas-, se yergue con noble aceptación de la inteligencia, don entre los dones.

37 El bacedor, p. 50. Más adelante se agrega: "Hace años yo traté de librarme de él y pasé de las mitologías del arrabal a los juegos con el tiempo y con lo infinito, pero esos juegos son de Borges ahora y tendré que idear otras cosas. Así mi vida es una fuga y todo lo pierdo y todo es del olvido, o del otro". (p. 51$)$.

38 Poemas (1922-1943), p. 9. 
"La parábola del palacio", incluida en El bacedor, cierra la interpretación de una vida de poeta con proyecciones que explican los desvelos creadores: "El poeta era esclavo del emperador y murió como tal; su composición cayó en el olvido porque merecía el olvido y sus descendientes buscan aún, y no encontrarán, la palabra del universo". ${ }^{39} \mathrm{Si}$ se aplica al mismo Borges esta tercera versión de un destino, las páginas desechadas en la Antología deben recontarse entre las distracciones con que quiso alcanzar expresivamente esa palabra inasible; las elegidas, en cambio, representan las aproximaciones felices a una continuidad casi eterna, en que la literatura es una forma de la metafísica, acaso de la religión.

Con criterio no falseado, podría afirmarse de Borges lo que él señaló en Quevedo: que es toda una literatura, más que un literato. De esta complejidad surgen los riesgos reservados al futuro; para entonces no sería difícil que Borges fuera sólo el autor de "determinados ejercicios de excesivo y apócrifo color local": "Hombre de la esquina rosada", el porteño evocador de Palermo y de Carriego, el contemplador de la luna, el ensayista que alabó con fe a'lgunas alegrías nacionales, o señaló con dolor las imposibilidades argentinas.

El Borges preferido por su autor no es el escritor amigo que se busca para compañía entrañable, sino el literato de la inteligencia y del rigor, el mayor estilista actual de la lengua española. Si el despojo de las notas regionales y el equilibrio de los elementos que confluyen en la creación literaria son los predicados de un clásico contemporáneo - un Valéry, un Eliot-, Borges representa en la América española esa categoría. ${ }^{40 c c i o ́ n ~ d e ~ r i g u r o s a ~ v i g i l a n c i a ~ e n t r e ~ q u i e n e s ~ t r a s l a d a n ~ a ~ s u s ~}$ páginas el caos circundante, prolongándolo como sectarios; rechazo, a la vez, del barroquismo decorativo y del romanticismo desorbitado que cargan la expresión de nuestro Continente.

\section{JuAN Carlos GHiano}

Facultad de Humanidades, Universidad Nacional de La Plata, Argentina.

39 El bacedor, p. 42.

140 "Valéry como símbolo" es el título de un ensayo de 1945, homenaje a "un hombre que, en un siglo que adora los caóticos ídolos de la sangre, de la tierra y de pasión, prefirió siempre los lúcidos placeres del pensamiento y las secretas aventuras del orden" (Otras inquisiciones, p. 90). 
